\title{
Effect of Mercury Stress on Photosynthetic Characteristics of Two Kinds of Warm Season Turf Grass
}

\author{
Yu-chen Guo, Ying-ying Liu, Rui-ying Wang, Sai Wang, Xiao-ping Lu, Bo Wang \\ Department of horticulture, Soochow University, Suzhou, China
}

Email address:

chenzi77@qq.com (Yu-chen Guo),wangb@sud.edu.cn (Bo Wang)

\section{To cite this article:}

Yu-chen Guo, Ying-ying Liu, Rui-ying Wang, Sai Wang, Xiao-ping Lu, Bo Wang. Effect of Mercury Stress on Photosynthetic Characteristics of Two Kinds of Warm Season Turf Grass. International Journal of Environmental Monitoring and Analysis. Vol. 3, No. 5, 2015, pp. $293-297$. doi: 10.11648/j.ijema.20150305.18

\begin{abstract}
In this paper, we adopted the pot simulation test method and took the plants that had been polluted by heavy metals as the research materials, to reveal the effect of mercury stress on photosynthetic characteristics and material production of turf grass. The results showed that, with the increase of the mercury stress intensity and the extension of time, the net photosynthetic rate $(\mathrm{Pn})$, stomatal conductance (Gs) and transpiration rate (Tr) of leaf of the two kinds of grass continued to decline, while the intercellular $\mathrm{CO}_{2}$ concentration $(\mathrm{Ci})$ continued to rise. The influence of mercury stress on photosynthetic characteristics of the two kinds of grass was shifting from stomatal limitation to non-stomatal limitation. The results of this study provide a theoretical basis for exploring the mechanism of mercury stress on the photosynthetic characteristics of turf grass.
\end{abstract}

Keywords: Mercury Stress, Turf Grass, Photosynthetic Characteristics

\section{Introduction}

With the rapid development of science and technology, the problems of population explosion, resource consumption, environmental pollution and ecological destruction are becoming increasingly prominent. The number of soil resources in China is gradually reduced, and the quality of it is constantly degraded. Not only that, heavy metal pollution, especially the soil mercury pollution is increasingly serious in the past few years and a series of mercury pollution incidents that have a significant impact have happened across China, which has a serious threat to China's food security. There are a lot of researches about the effects of mercury on the growth and development of plants both at international. At present, the effects of mercury stress on the plants are mainly concentrated in the aspects of cell membrane permeability, photosynthesis and protective enzyme system. In the study of membrane permeability of pumpkin cells, CHRISTOS et al found that the permeability of the plasma membrane to water was decreased, and the absorption of boron was also decreased when the cells were treated with mercury [1]. In the study of protective enzyme system of radish seedlings, some scholars found that mercury can stimulate the production of POD during the processing, and the POD increased with the increase of the concentration of mercury [2]. In the study of photosynthesis of plants, KRAUSE et al reported that the peak of the fluorescence at $685 \mathrm{~nm}$ and $740 \mathrm{~nm}$ was significantly decreased after treated with mercury. Therefore, he believed that the change of fluorescence emission peak was mainly due to the binding states of the PSII in the photosynthetic membrane and the chlorophyll molecules of the light harvesting system were seriously affected by mercury [3]. On the contrary, the overwintering buds of water shield treated with different concentrations of mercury, did not produce significant changes on photosynthetic membrane polypeptide components [4].

But most of them are concentrated on the effects of the yield and quality of crops and economic crops. Yet the research on the growth and development of landscape plants is only a little bit $[5,6]$.

We took the two kinds of turf grass, Eremochloa ophiuroides (Munro) Hack and Axonopus compressus (Sw.) Beauv as the research materials, which is often used in Suzhou and has some representation, to study the effects of different concentrations of mercury stress on photosynthetic characteristics of them. In order to provide a theoretical basis for the research on the tolerance of mercury, the mechanism of mercury resistance, and the cultivation of warm season turf grass which has resistance to mercury in Suzhou area. 


\section{Experimental Materials and Methods}

\subsection{Experimental Materials}

The experimental materials are two kinds of turf grass-Eremochloa ophiuroides (Munro) Hack and Axonopus compressus (Sw.) Beauv, which is provided by Beijing bright grass Co Ltd. The experimental soil samples are taken from Kunshan, Jiangsu. The basic physical and chemical properties of it see Table 1. The test soil need to be treated with natural air drying, grinding and $5 \mathrm{~mm}$ screen sieving. Reagents used in the experiment were all analysis of pure.

Table 1. The basic physical and chemical properties of the tested soils.

\begin{tabular}{lllllll}
\hline $\mathbf{p H}$ & Soil texture & Volume weight $\left(\mathbf{g} \cdot \mathbf{c m}^{-3}\right)$ & Porosity $\mathbf{( \% )}$ & Organic matter $\left(\mathbf{g} \cdot \mathbf{k g} \mathbf{- 1}^{-1}\right)$ & Avai. $\left.\mathbf{P}(\mathbf{m g} \cdot \mathbf{k g})^{-1}\right)$ & $\mathbf{A v a i} \cdot \mathbf{~ K}\left(\mathbf{m g} \cdot \mathbf{k g}^{-1}\right)$ \\
\hline 6.63 & Tight sand & 0.96 & 63.77 & 15.66 & 3.82 & 136.37 \\
\hline
\end{tabular}

\subsection{Experimental Methods}

This experiment uses a pot simulation method. The air dry soil for the test was put into the PVC plastic basin, which has the diameter of $10 \mathrm{~cm}, 9 \mathrm{~cm}$ and $0.6 \mathrm{~kg}$ per pot. To take $\mathrm{HgCl}_{2}$ for exogenous mercury, mercury concentration in soil were increased by $0 \mathrm{mg} \mathrm{kg}^{-1}(\mathrm{CK}), 0.5 \mathrm{mg} \mathrm{kg}^{-1}$ (treatment A), 1.0 $\mathrm{mg} \mathrm{kg}^{-1}$ (B), $3.0 \mathrm{mg} \mathrm{kg}^{-1}$ (C), $5.0 \mathrm{mg} \mathrm{kg}^{-1}$ (D), $10.0 \mathrm{mg} \mathrm{kg}^{-1}$ (E), $30.0 \mathrm{mg} \mathrm{kg}^{-1}$ (F), $60.0 \mathrm{mg} \mathrm{kg}^{-1}(\mathrm{G}), 120 \mathrm{mg} \mathrm{kg}^{-1}$ (H). Each treatment set five repeated. Chose healthy plump seeds of uniform size and disinfected for 10 min with $0.5 \%$ potassium permanganate solution before planting. Then washed clean them with distilled water repeatedly and soaked them in sterile water for $24 \mathrm{~h}$. Finally, evenly spread the germinating seeds on the earth, cover with $0.5 \mathrm{~cm}$ air dried soil and compacted it lightly. Then placed them in the $25 \pm 2{ }^{\circ} \mathrm{C}$ incubators to culture, were observed daily and replenish moisture. Make an observation daily and make a replenishment of water timely. The sowing rate was 200 per pot. After the turf grass to be maturation $(30 \mathrm{~d})$, then began to measure the indicators every $15 \mathrm{~d}$, a total of 3 times, each treatment with 3 times.

\subsection{Data Collecting and Processing}

Photosynthetic characteristics were measured by LI-6400 portable photosynthesis (LI-COR, USA), and the flow rate was set to $500 \mu \mathrm{mol} \cdot \mathrm{s}^{-1}$, the light intensity is set to 1500 $\mu \mathrm{mol} \cdot \mathrm{m}^{-2} \mathrm{~s}^{-1}$, and the $\mathrm{CO}_{2}$ concentration of the atmosphere is controlled at $400 \mu \mathrm{mol} \cdot \mathrm{mol}^{-1}$. The time of Determination was chosen at 8:00-11:00 am. We selected the measured leaf with same age and same position. The measured indicators including the net photosynthetic rate $(\mathrm{Pn})$, stomatal conductance (Gs), intercellular $\mathrm{CO}_{2}$ concentration $(\mathrm{Ci})$ and transpiration rate (Tr). Microsoft Excel 2013 and IBM SPSS STATISTICS 19.0 were used to do the date analyses processing [7].

\section{Results and Analysis}

\subsection{Effects of Different Concentrations of $\mathrm{Hg}^{2+}$ on Net Photosynthetic of Leaves}

Table 2 showed that with the increase of mercury concentration, the Pn of Axonopus compressus (Sw.) Beauv of CK, A, B, C, D, E, F, G, and H showed a gradually decreasing trend, were $6.45 \mu \mathrm{mol} \cdot \mathrm{m}^{-2} \cdot \mathrm{s}^{-1} 、 5.83 \mu \mathrm{mol} \cdot \mathrm{m}^{-2} \cdot \mathrm{s}^{-1} 、 5.12$ $\mu \mathrm{mol} \cdot \mathrm{m}^{-2} \cdot \mathrm{s}^{-1} 、 4.32 \mu \mathrm{mol} \cdot \mathrm{m}^{-2} \cdot \mathrm{s}^{-1} 、 3.96 \mu \mathrm{mol} \cdot \mathrm{m}^{-2} \cdot \mathrm{s}^{-1} 、 3.81$ $\mu \mathrm{mol} \cdot \mathrm{m}^{-2} \cdot \mathrm{s}^{-1} 、 3.24 \mu \mathrm{mol} \cdot \mathrm{m}^{-2} \cdot \mathrm{s}^{-1} 、 2.79 \mu \mathrm{mol} \cdot \mathrm{m}^{-2} \cdot \mathrm{s}^{-1}$ and 1.85 $\mu \mathrm{mol} \cdot \mathrm{m}^{-2} \cdot \mathrm{s}^{-1}$ respectively(the average of $30^{\text {th }} \mathrm{d}, 45^{\text {th }} \mathrm{d}$ and $60^{\text {th }}$ d). The Pn of the treatments of A, B, C, D, E, F, G, and H were $96.46 \%, 76.01 \%, 66.19 \%, 72.36 \%, 67.04 \%, 59.64 \%, 60.34 \%$ and $52.19 \%$ of CK respectively on the $30^{\text {th }} \mathrm{d}$. Among them, in addition to the $\mathrm{CK}, \mathrm{A}, \mathrm{B}, \mathrm{G}$ and $\mathrm{H}$, the difference between the treatments have reached a significant level, the rest of the treatments have no significant difference. With the extension of the processing time, the difference between the treatments increased significantly, the difference of the treatments reached a significant level at all on $60^{\text {th }} \mathrm{d}$. The experimental results of Eremochloa ophiuroides (Munro) Hack also showed the same variation trend. The Pn of it of CK, A, B, C, D, E, F, $\mathrm{G}$ and $\mathrm{H}$ were $7.24 \mu \mathrm{mol} \cdot \mathrm{m}^{-2} \cdot \mathrm{s}^{-1} 、 7.22 \mu \mathrm{mol} \cdot \mathrm{m}^{-2} \cdot \mathrm{s}^{-1} 、 6.93$ $\mu \mathrm{mol} \cdot \mathrm{m}^{-2} \cdot \mathrm{s}^{-1} 、 5.51 \mu \mathrm{mol} \cdot \mathrm{m}^{-2} \cdot \mathrm{s}^{-1} 、 5.28 \mu \mathrm{mol} \cdot \mathrm{m}^{-2} \cdot \mathrm{s}^{-1} 、 4.93$ $\mu \mathrm{mol} \cdot \mathrm{m}^{-2} \cdot \mathrm{s}^{-1} 、 4.40 \mu \mathrm{mol} \cdot \mathrm{m}^{-2} \cdot \mathrm{s}^{-1} 、 3.34 \mu \mathrm{mol} \cdot \mathrm{m}^{-2} \cdot \mathrm{s}^{-1}$ and 2.32 $\mu \mathrm{mol} \cdot \mathrm{m}^{-2} \cdot \mathrm{s}^{-1}$ respectively(the average of $30^{\text {th }} \mathrm{d}, 45^{\text {th }} \mathrm{d}$ and $60^{\text {th }}$ d). It is worth noting that, the Pn of A and B treatments are slightly increased than $\mathrm{CK}$ on the $45^{\text {th }} \mathrm{d}$, which may be interpreted as different turf grass had different adaptability to mercury stress, and with further increase in mercury stress intensity, each treatment is gradually reduced.

\subsection{Effects of Different Concentrations of $\mathrm{Hg}^{2+}$ on Stomatal Conductance of Leaves}

Table 3 showed that with the increase of mercury concentration, the $\mathrm{Tr}$ of Axonopus compressus (Sw.) Beauv of $\mathrm{CK}, \mathrm{A}, \mathrm{B}, \mathrm{C}, \mathrm{D}, \mathrm{E}, \mathrm{F}, \mathrm{G}$, and $\mathrm{H}$ showed a gradually decreasing trend, were $0.15 \mathrm{mmol} \cdot \mathrm{m}^{-2} \cdot \mathrm{s}^{-1} 、 0.13 \mathrm{mmol} \cdot \mathrm{m}^{-2} \cdot \mathrm{s}^{-1}$ 、 $0.11 \mathrm{mmol} \cdot \mathrm{m}^{-2} \cdot \mathrm{s}^{-1} 、 0.11 \mathrm{mmol} \cdot \mathrm{m}^{-2} \cdot \mathrm{s}^{-1} 、 0.10 \mathrm{mmol} \cdot \mathrm{m}^{-2} \cdot \mathrm{s}^{-1}$ 、 $0.10 \mathrm{mmol} \cdot \mathrm{m}^{-2} \cdot \mathrm{s}^{-1} 、 0.07 \mathrm{mmol} \cdot \mathrm{m}^{-2} \cdot \mathrm{s}^{-1} 、 0.05 \mathrm{mmol} \cdot \mathrm{m}^{-2} \cdot \mathrm{s}^{-1}$ and $0.05 \mathrm{mmol} \cdot \mathrm{m}^{-2} \cdot \mathrm{s}^{-1}$ respectively(the average of $30^{\text {th }} \mathrm{d}, 45^{\text {th }}$ $\mathrm{d}$ and $60^{\text {th }} \mathrm{d}$ ). The Gs of the treatments of A, B, C, D, E, F, G, and $\mathrm{H}$ were $87.50 \% 、 62.50 \% 、 75.00 \% 、 62.50 \% 、 62.50 \%$ 、 $50.00 \% 、 37.50 \%$ and $37.50 \%$ of CK respectively on the $30^{\text {th }}$ d. Among them, the difference between the treatments and the CK have reached a significant level, but there have no significant difference between each treatment. The results of the $45^{\text {th }} \mathrm{d}$ and the $60^{\text {th }} \mathrm{d}$ were similar to the $30^{\text {th }} \mathrm{d}$. The experimental results of Eremochloa ophiuroides (Munro) Hack also showed the same variation trend. The Gs of it of $\mathrm{CK}, \mathrm{A}, \mathrm{B}, \mathrm{C}, \mathrm{D}, \mathrm{E}, \mathrm{F}, \mathrm{G}$ and $\mathrm{H}$ were $0.14 \mathrm{mmol} \cdot \mathrm{m}^{-2} \cdot \mathrm{s}^{-1}$ 、 0.13 $\mathrm{mmol} \cdot \mathrm{m}^{-2} \cdot \mathrm{s}^{-1} 、 0.11 \mathrm{mmol} \cdot \mathrm{m}^{-2} \cdot \mathrm{s}^{-1} 、 0.09 \mathrm{mmol} \cdot \mathrm{m}^{-2} \cdot \mathrm{s}^{-1} 、 0.09$ $\mathrm{mmol} \cdot \mathrm{m}^{-2} \cdot \mathrm{s}^{-1} 、 0.10 \mathrm{mmol} \cdot \mathrm{m}^{-2} \cdot \mathrm{s}^{-1} 、 0.08 \mathrm{mmol} \cdot \mathrm{m}^{-2} \cdot \mathrm{s}^{-1} 、 0.06$ $\mathrm{mmol} \cdot \mathrm{m}^{-2} \cdot \mathrm{s}^{-1}$ and $0.05 \mathrm{mmol} \cdot \mathrm{m}^{-2} \cdot \mathrm{s}^{-1}$ respectively (the average of $30^{\text {th }} \mathrm{d}, 45^{\text {th }} \mathrm{d}$ and $60^{\text {th }} \mathrm{d}$ ). 


\subsection{Effects of Different Concentrations of $\mathrm{Hg}^{2+}$ on Intercellular $\mathrm{CO}_{2}$ Concentration of Leaves}

Table 4 showed that with the increase of mercury concentration, the $\mathrm{Ci}$ of Axonopus compressus (Sw.) Beauv of CK, A, B, C, D, E, F, G, and H showed a gradually increasing trend, were $313.89 \mu \mathrm{mol} \cdot \mathrm{mol}^{-1} 、 314.18 \mu \mathrm{mol} \cdot \mathrm{mol}^{-1} 、 317.38$ $\mu \mathrm{mol} \cdot \mathrm{mol}^{-1} 、 319.30 \mu \mathrm{mol} \cdot \mathrm{mol}^{-1} 、 326.97 \mu \mathrm{mol} \cdot \mathrm{mol}^{-1} 、 336.17$ $\mu \mathrm{mol} \cdot \mathrm{mol}^{-1}$ 、338.34 $\mu \mathrm{mol}^{\circ} \mathrm{mol}^{-1}$ 、346.31 $\mu \mathrm{mol}^{-} \mathrm{mol}^{-1}$ and $354.11 \mu \mathrm{mol} \cdot \mathrm{mol}^{-1}$ respectively(the average of $30^{\text {th }} \mathrm{d}, 45^{\text {th }} \mathrm{d}$ and $60^{\text {th }} \mathrm{d}$ ). The $\mathrm{Ci}$ of the treatments of $\mathrm{A}, \mathrm{B}$ and $\mathrm{C}$ were $99.33 \%, 97.50 \%$ and $92.51 \%$ of CK respectively on the $30^{\text {th }} d$, however with the increase of mercury concentration, the $\mathrm{Ci}$ of the treatments of D, E, F, G and H were $100.65 \%$ 、 $101.55 \%$ 、 $102.68 \%, 103.76 \%$ and $107.53 \%$ of CK respectively, which showed a growing trend. Among them, in addition to the A and $\mathrm{B}$, the difference between the treatments with $\mathrm{CK}$ have all reached a significant level. With the extension of the processing time, the difference between the treatments increased significantly, the difference of the treatments reached a significant level at all on $60^{\text {th }} \mathrm{d}$. The experimental results of Eremochloa ophiuroides (Munro) Hack also showed the same variation trend. The $\mathrm{Ci}$ of it of CK, A, B, C, D, E, F, $\mathrm{G}$ and $\mathrm{H}$ were $277.34 \mu \mathrm{mol} \cdot \mathrm{mol}^{-1}$ 、 $288.08 \mu \mathrm{mol} \cdot \mathrm{mol}^{-1}$ 、 300.07 $\mu \mathrm{mol} \cdot \mathrm{mol}^{-1} 、 302.93 \mu \mathrm{mol} \cdot \mathrm{mol}^{-1} 、 301.99 \mu \mathrm{mol} \cdot \mathrm{mol}^{-1}$ 、 314.30 $\mu \mathrm{mol} \cdot \mathrm{mol}^{-1}$ 、316.84 $\mu \mathrm{mol} \cdot \mathrm{mol}^{-1}$ 、 $327.43 \mu \mathrm{mol}^{\circ} \mathrm{mol}^{-1}$ and $325.69 \mu \mathrm{mol} \cdot \mathrm{mol}^{-1}$ respectively(the average of $30^{\text {th }} \mathrm{d}, 45^{\text {th }} \mathrm{d}$ and $\left.60^{\text {th }} \mathrm{d}\right)$.

\subsection{Effects of Different Concentrations of $\mathrm{Hg}^{2+}$ on Transpiration Rate of Leaves}

Table 2. Effects of different concentrations of $\mathrm{Hg}^{2+}$ on net photosynthetic of leaves.

\begin{tabular}{|c|c|c|c|c|c|c|}
\hline \multirow{3}{*}{ Treatments } & \multicolumn{6}{|c|}{ 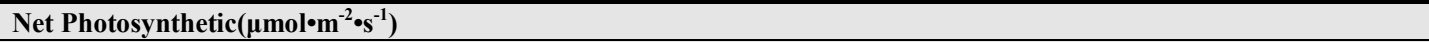 } \\
\hline & \multicolumn{3}{|c|}{ Axonopus compressus (Sw.) Beauv } & \multicolumn{3}{|c|}{ Eremochloa ophiuroides (Munro) Hack } \\
\hline & $30^{\text {th }} \mathrm{d}$ & $45^{\text {th }} d$ & $60^{\text {th }} \mathrm{d}$ & $30^{\text {th }} \mathrm{d}$ & $45^{\text {th }} d$ & $60^{\text {th }} \mathrm{d}$ \\
\hline CK & $6.65 \pm 0.11 \mathrm{a}$ & $6.52 \pm 0.21 \mathrm{a}$ & $6.17 \pm 0.09 \mathrm{a}$ & $7.53 \pm 0.33 \mathrm{a}$ & $7.35 \pm 0.20 \mathrm{~b}$ & $6.84 \pm 0.04 \mathrm{a}$ \\
\hline A & $6.42 \pm 0.18 \mathrm{a}$ & $5.71 \pm 0.23 b$ & $5.36 \pm 0.08 b$ & $6.80 \pm 0.18 b$ & $8.29 \pm 0.44 \mathrm{a}$ & $6.57 \pm 0.08 b$ \\
\hline B & $5.06 \pm 0.33 b$ & $5.25 \pm 0.48 b$ & $5.04 \pm 0.08 \mathrm{c}$ & $6.63 \pm 0.17 \mathrm{bc}$ & $7.82 \pm 0.28 \mathrm{ab}$ & $6.34 \pm 0.06 \mathrm{c}$ \\
\hline $\mathrm{C}$ & $4.40 \pm 0.17 \mathrm{~cd}$ & $4.44 \pm 0.46 \mathrm{c}$ & $4.12 \pm 0.10 \mathrm{~d}$ & $6.11 \pm 0.32 \mathrm{~cd}$ & $5.23 \pm 0.43 c$ & $5.20 \pm 0.14 d$ \\
\hline $\mathrm{D}$ & $4.81 \pm 0.37 \mathrm{bc}$ & $3.65 \pm 0.22 \mathrm{~d}$ & $3.43 \pm 0.14 \mathrm{e}$ & $6.45 \pm 0.23 b c$ & $4.71 \pm 0.45 \mathrm{~cd}$ & $4.68 \pm 0.08 \mathrm{e}$ \\
\hline $\mathrm{F}$ & $3.97 \pm 0.25 \mathrm{de}$ & $3.02 \pm 0.20 \mathrm{e}$ & $2.72 \pm 0.09 \mathrm{~g}$ & $5.54 \pm 0.30 \mathrm{e}$ & $3.88 \pm 0.24 \mathrm{e}$ & $3.79 \pm 0.05 f$ \\
\hline G & $4.01 \pm 0.27 \mathrm{~d}$ & $2.50 \pm 0.20 \mathrm{e}$ & $1.86 \pm 0.09 \mathrm{~h}$ & $4.72 \pm 0.15 f$ & $2.77 \pm 0.40 \mathrm{f}$ & $2.52 \pm 0.10 \mathrm{~g}$ \\
\hline $\mathrm{H}$ & $3.47 \pm 0.17 \mathrm{e}$ & $1.03 \pm 0.22 \mathrm{f}$ & $1.06 \pm 0.05 \mathrm{i}$ & $2.66 \pm 0.18 \mathrm{~g}$ & $2.22 \pm 0.28 \mathrm{f}$ & $2.07 \pm 0.10 \mathrm{~h}$ \\
\hline
\end{tabular}

NOTE: CK, A, B, C, D, E, F, G and H were represented the added concentrations of $\mathrm{Hg}^{2+}$ in soil $0.0,0.5,1.0,3.0,5.0,10.0,30.0,60.0,120.0 \mathrm{mg} \bullet \mathrm{kg}^{-1}$, respectively. Different letters mean significant difference at 0.05 level between treatments. The same below.

Table 3. Effects of different concentrations of $\mathrm{Hg}^{2+}$ on stomatal conductance of leaves.

\begin{tabular}{|c|c|c|c|c|c|c|}
\hline \multirow{3}{*}{ Treatments } & \multicolumn{6}{|c|}{ Stomatal Conductance $\left(\mathrm{mmol}^{\circ} \mathrm{m}^{-2} \cdot \mathrm{s}^{-1}\right)$} \\
\hline & \multicolumn{3}{|c|}{ Axonopus compressus (Sw.) Beauv } & \multicolumn{3}{|c|}{ Eremochloa ophiuroides (Munro) Hack } \\
\hline & $30^{\text {th }} \mathrm{d}$ & $45^{\text {th }} \mathrm{d}$ & $60^{\text {th }} \mathrm{d}$ & $30^{\text {th }} d$ & $45^{\text {th }} \mathrm{d}$ & $60^{\text {th }} \mathrm{d}$ \\
\hline CK & $0.16 \pm 0.00 \mathrm{a}$ & $0.14 \pm 0.01 \mathrm{a}$ & $0.14 \pm 0.01 \mathrm{a}$ & $0.15 \pm 0.01 \mathrm{a}$ & $0.14 \pm 0.01 \mathrm{ab}$ & $0.13 \pm 0.00 \mathrm{a}$ \\
\hline A & $0.14 \pm 0.00 \mathrm{~b}$ & $0.12 \pm 0.01 b$ & $0.12 \pm 0.01 b$ & $0.11 \pm 0.01 b$ & $0.15 \pm 0.01 \mathrm{a}$ & $0.12 \pm 0.00 \mathrm{~b}$ \\
\hline $\mathrm{B}$ & $0.10 \pm 0.00 \mathrm{e}$ & $0.11 \pm 0.01 b$ & $0.11 \pm 0.01 b$ & $0.10 \pm 0.01 b c$ & $0.13 \pm 0.01 b$ & $0.11 \pm 0.00 \mathrm{c}$ \\
\hline $\mathrm{C}$ & $0.12 \pm 0.00 \mathrm{c}$ & $0.11 \pm 0.01 b$ & $0.10 \pm 0.01 \mathrm{c}$ & $0.09 \pm 0.01 \mathrm{c}$ & $0.09 \pm 0.01 \mathrm{c}$ & $0.09 \pm 0.00 \mathrm{~d}$ \\
\hline $\mathrm{D}$ & $0.10 \pm 0.00 \mathrm{e}$ & $0.10 \pm 0.01 b$ & $0.09 \pm 0.01 \mathrm{c}$ & $0.10 \pm 0.01 \mathrm{c}$ & $0.08 \pm 0.01 \mathrm{~cd}$ & $0.08 \pm 0.00 \mathrm{e}$ \\
\hline $\mathrm{E}$ & $0.10 \pm 0.00 \mathrm{~d}$ & $0.11 \pm 0.01 b$ & $0.09 \pm 0.01 \mathrm{c}$ & $0.12 \pm 0.01 b$ & $0.09 \pm 0.01 \mathrm{c}$ & $0.08 \pm 0.00 \mathrm{e}$ \\
\hline $\mathrm{F}$ & $0.08 \pm 0.00 \mathrm{f}$ & $0.08 \pm 0.01 \mathrm{c}$ & $0.06 \pm 0.01 \mathrm{~d}$ & $0.10 \pm 0.00 \mathrm{c}$ & $0.08 \pm 0.01 \mathrm{~cd}$ & $0.06 \pm 0.00 \mathrm{f}$ \\
\hline G & $0.06 \pm 0.00 \mathrm{~g}$ & $0.06 \pm 0.01 \mathrm{~cd}$ & $0.04 \pm 0.00 \mathrm{e}$ & $0.07 \pm 0.01 d$ & $0.07 \pm 0.01 \mathrm{de}$ & $0.05 \pm 0.00 \mathrm{fg}$ \\
\hline $\mathrm{H}$ & $0.06 \pm 0.00 \mathrm{~h}$ & $0.05 \pm 0.01 \mathrm{~d}$ & $0.04 \pm 0.01 \mathrm{e}$ & $0.05 \pm 0.01 \mathrm{~d}$ & $0.05 \pm 0.01 \mathrm{e}$ & $0.05 \pm 0.00 \mathrm{~g}$ \\
\hline
\end{tabular}

Table 4. Effects of different concentrations of $\mathrm{Hg}^{2+}$ on intercellular $\mathrm{CO}_{2}$ concentration of leaves.

\begin{tabular}{|c|c|c|c|c|c|c|}
\hline \multirow{3}{*}{ Treatments } & \multicolumn{6}{|c|}{ Intercellular $\mathrm{CO}_{2}$ Concentration $\left(\mu \mathrm{mol} \cdot \mathrm{mol}^{-1}\right)$} \\
\hline & \multicolumn{3}{|c|}{ Axonopus compressus (Sw.) Beauv } & \multicolumn{3}{|c|}{ Eremochloa ophiuroides (Munro) Hack } \\
\hline & $30^{\text {th }} \mathrm{d}$ & $45^{\text {th }} d$ & $60^{\text {th }} \mathrm{d}$ & $30^{\text {th }} \mathrm{d}$ & $45^{\text {th }} d$ & $60^{\text {th }} \mathrm{d}$ \\
\hline CK & $317.04 \pm 5.46 \mathrm{cde}$ & $313.15 \pm 4.28 \mathrm{de}$ & $311.47 \pm 1.30 \mathrm{~g}$ & $282.42 \pm 2.97 \mathrm{e}$ & $286.23 \pm 4.86 \mathrm{e}$ & $263.37 \pm 2.15 \mathrm{i}$ \\
\hline A & $314.90 \pm 3.97 \mathrm{de}$ & $310.50 \pm 6.30 \mathrm{de}$ & $317.14 \pm 1.28 \mathrm{f}$ & $290.14 \pm 3.56 \mathrm{de}$ & $295.96 \pm 4.08 \mathrm{~d}$ & $278.13 \pm 2.74 \mathrm{~h}$ \\
\hline $\mathrm{B}$ & $309.11 \pm 3.23 \mathrm{e}$ & $306.58 \pm 5.00 \mathrm{e}$ & $336.44 \pm 1.21 \mathrm{e}$ & $297.61 \pm 5.55 \mathrm{~cd}$ & $294.82 \pm 3.14 \mathrm{de}$ & $307.79 \pm 0.97 f$ \\
\hline $\mathrm{C}$ & $293.28 \pm 5.09 \mathrm{f}$ & $319.06 \pm 5.51 \mathrm{~cd}$ & $345.57 \pm 2.49 d$ & $301.69 \pm 3.65 \mathrm{bc}$ & $294.01 \pm 5.61 \mathrm{de}$ & $313.09 \pm 1.19 \mathrm{e}$ \\
\hline $\mathrm{D}$ & $319.09 \pm 4.23 \mathrm{~cd}$ & $325.82 \pm 3.39 c$ & $336.01 \pm 1.25 \mathrm{e}$ & $299.47 \pm 4.37 \mathrm{bc}$ & $305.88 \pm 5.71 \mathrm{c}$ & $300.61 \pm 2.99 \mathrm{~g}$ \\
\hline $\mathrm{E}$ & $321.95 \pm 5.57 \mathrm{bcd}$ & $339.62 \pm 3.50 \mathrm{ab}$ & $346.93 \pm 2.50 \mathrm{~d}$ & $304.95 \pm 3.13 b c$ & $309.80 \pm 4.44 \mathrm{bc}$ & $328.16 \pm 0.90 \mathrm{c}$ \\
\hline $\mathrm{F}$ & $325.54 \pm 3.25 b c$ & $336.99 \pm 4.49 b$ & $352.48 \pm 0.96 c$ & $308.12 \pm 4.02 b$ & $318.64 \pm 2.99 \mathrm{ab}$ & $323.76 \pm 1.06 \mathrm{~d}$ \\
\hline G & $328.97 \pm 4.27 b$ & $346.42 \pm 3.04 \mathrm{ab}$ & $363.53 \pm 1.45 b$ & $317.55 \pm 3.73 \mathrm{a}$ & $318.99 \pm 3.77 \mathrm{ab}$ & $345.75 \pm 1.24 b$ \\
\hline $\mathrm{H}$ & $340.92 \pm 2.64 a$ & $349.06 \pm 4.57 \mathrm{a}$ & $372.35 \pm 1.23 \mathrm{a}$ & $317.89 \pm 4.51 \mathrm{a}$ & $322.00 \pm 2.39 a$ & $337.19 \pm 2.22 \mathrm{a}$ \\
\hline
\end{tabular}


Table 5. Effects of different concentrations of $\mathrm{Hg}^{2+}$ on transpiration rate of leaves.

\begin{tabular}{|c|c|c|c|c|c|c|}
\hline \multirow{3}{*}{ Treatments } & \multicolumn{6}{|c|}{ Transpiration Rate $\left(\mathrm{mmol}^{\circ} \mathrm{m}^{-2} \cdot \mathrm{s}^{-1}\right)$} \\
\hline & \multicolumn{3}{|c|}{ Axonopus compressus (Sw.) Beauv } & \multicolumn{3}{|c|}{ Eremochloa ophiuroides (Munro) Hack } \\
\hline & $30^{\text {th }} \mathrm{d}$ & $45^{\text {th }} \mathrm{d}$ & $60^{\text {th }} \mathrm{d}$ & $30^{\text {th }} d$ & $45^{\text {th }} d$ & $60^{\text {th }} \mathrm{d}$ \\
\hline CK & $6.50 \pm 0.14 \mathrm{a}$ & $6.45 \pm 0.14 a$ & $3.60 \pm 0.01 \mathrm{a}$ & $5.98 \pm 0.33 \mathrm{ab}$ & $5.81 \pm 0.32 \mathrm{a}$ & $3.77 \pm 0.00 \mathrm{a}$ \\
\hline A & $5.40 \pm 0.23 b$ & $5.35 \pm 0.10 \mathrm{~b}$ & $2.37 \pm 0.00 \mathrm{e}$ & $6.35 \pm 0.36 \mathrm{a}$ & $6.16 \pm 0.24 a$ & $3.57 \pm 0.02 b$ \\
\hline B & $6.41 \pm 0.19 a$ & $4.96 \pm 0.23 b$ & $2.5 \pm 0.02 \mathrm{c}$ & $5.45 \pm 0.10 \mathrm{~b}$ & $5.14 \pm 0.37 b$ & $3.06 \pm 0.01 \mathrm{c}$ \\
\hline $\mathrm{C}$ & $5.79 \pm 0.32 b$ & $4.39 \pm 0.20 \mathrm{c}$ & $2.60 \pm 0.01 \mathrm{~b}$ & $4.44 \pm 0.15 c$ & $3.66 \pm 0.23 c$ & $2.89 \pm 0.03 \mathrm{~d}$ \\
\hline D & $5.77 \pm 0.11 b$ & $3.67 \pm 0.11 \mathrm{~d}$ & $2.48 \pm 0.01 \mathrm{~d}$ & $3.35 \pm 0.36 \mathrm{de}$ & $3.32 \pm 0.25 c$ & $2.68 \pm 0.03 \mathrm{efg}$ \\
\hline $\mathrm{E}$ & $5.56 \pm 0.15 b$ & $3.40 \pm 0.12 \mathrm{de}$ & $2.29 \pm 0.01 \mathrm{f}$ & $3.76 \pm 0.21 \mathrm{~d}$ & $3.26 \pm 0.31 \mathrm{~cd}$ & $2.65 \pm 0.01 \mathrm{f}$ \\
\hline $\mathrm{F}$ & $4.23 \pm 0.12 \mathrm{c}$ & $3.08 \pm 0.40 \mathrm{e}$ & $2.03 \pm 0.00 \mathrm{~g}$ & $3.15 \pm 0.23 \mathrm{ef}$ & $2.69 \pm 0.29 \mathrm{de}$ & $2.50 \pm 0.00 \mathrm{~g}$ \\
\hline G & $3.12 \pm 0.32 \mathrm{~d}$ & $2.56 \pm 0.20 \mathrm{f}$ & $1.43 \pm 0.00 \mathrm{~h}$ & $2.68 \pm 0.14 \mathrm{fg}$ & $2.10 \pm 0.17 \mathrm{ef}$ & $2.20 \pm 0.01 \mathrm{~h}$ \\
\hline $\mathrm{H}$ & $3.08 \pm 0.16 \mathrm{~d}$ & $1.70 \pm 0.27 \mathrm{~g}$ & $1.11 \pm 0.00 \mathrm{i}$ & $2.38 \pm 0.30 \mathrm{~g}$ & $1.68 \pm 0.28 \mathrm{f}$ & $1.89 \pm 0.00 \mathrm{i}$ \\
\hline
\end{tabular}

Table 5 showed that with the increase of mercury concentration, the Pn of Axonopus compressus (Sw.) Beauv of CK, A, B, C, D, E, F, G, and H showed a gradually decreasing trend, were $5.52 \mathrm{mmol} \cdot \mathrm{m}^{-2} \cdot \mathrm{s}^{-1} 、 4.37 \mathrm{mmol} \cdot \mathrm{m}^{-2} \cdot \mathrm{s}^{-1} 、 4.62$ $\mathrm{mmol} \cdot \mathrm{m}^{-2} \cdot \mathrm{s}^{-1} 、 4.26 \mathrm{mmol} \cdot \mathrm{m}^{-2} \cdot \mathrm{s}^{-1} 、 3.97 \mathrm{mmol} \cdot \mathrm{m}^{-2} \cdot \mathrm{s}^{-1} 、 3.75$ $\mathrm{mmol} \cdot \mathrm{m}^{-2} \cdot \mathrm{s}^{-1} 、 3.11 \mathrm{mmol} \cdot \mathrm{m}^{-2} \cdot \mathrm{s}^{-1} 、 2.37 \mathrm{mmol} \cdot \mathrm{m}^{-2} \cdot \mathrm{s}^{-1}$ and 1.96 $\mathrm{mmol} \cdot \mathrm{m}^{-2} \cdot \mathrm{s}^{-1}$ respectively(the average of $30^{\text {th }} \mathrm{d}, 45^{\text {th }} \mathrm{d}$ and $60^{\text {th }}$ d). The Tr of the treatments of A, B, C, D, E, F, G, and H were $83.08 \% 、 98.62 \% 、 89.08 \% 、 88.77 \% 、 85.54 \% 、 65.08 \%$ 、 $48.00 \%$ and $47.38 \%$ of CK respectively on the $30^{\text {th }} \mathrm{d}$. It is worth noting that, the experimental results of Eremochloa ophiuroides (Munro) Hack showed the different variation trend, it showing a trend of increased first and then decreased The Tr of it of CK, A, B, C, D, E, F, G and H were 5.19 $\mathrm{mmol} \cdot \mathrm{m}^{-2} \cdot \mathrm{s}^{-1} 、 5.36 \mathrm{mmol} \cdot \mathrm{m}^{-2} \cdot \mathrm{s}^{-1} 、 4.55 \mathrm{mmol} \cdot \mathrm{m}^{-2} \cdot \mathrm{s}^{-1} 、 3.66$ $\mathrm{mmol} \cdot \mathrm{m}^{-2} \cdot \mathrm{s}^{-1} 、 3.12 \mathrm{mmol} \cdot \mathrm{m}^{-2} \cdot \mathrm{s}^{-1} 、 3.22 \mathrm{mmol} \cdot \mathrm{m}^{-2} \cdot \mathrm{s}^{-1} 、 2.78$ $\mathrm{mmol} \cdot \mathrm{m}^{-2} \cdot \mathrm{s}^{-1} 、 2.33 \mathrm{mmol} \cdot \mathrm{m}^{-2} \cdot \mathrm{s}^{-1}$ and $1.98 \mathrm{mmol} \cdot \mathrm{m}^{-2} \cdot \mathrm{s}^{-1}$ respectively(the average of $30^{\text {th }} \mathrm{d}, 45^{\text {th }} \mathrm{d}$ and $60^{\text {th }} \mathrm{d}$.

\section{Discussions and Conclusions}

The intensity of photosynthesis reflects the size of capacity of $\mathrm{CO}_{2}$ fixed of the plant, which performance for the accumulation of organic matter. Net photosynthetic rate refers to the rate of carbohydrate produced by total photosynthesis minus the rate of respiration, which is expressed by the absorption of carbon dioxide micro molar number per square of leaf area and per second. The numerical value can reflect the plant's ability to absorb carbon dioxide. The research results showed that mercury stress can lead to a decline in Pn of turf grass, and with the intensity of mercury stress increased and time prolonged, the Pn continued to decline. In the research of the Pn of the Axonopus compressus (Sw.) Beauv, it was found that even the lower soil mercury concentration can cause the Pn decline rapidly, and with the extension of time, the Pn of each treatment also showed a gradual downward trend. However, after the decline of Pn of each treatment of Eremochloa ophiuroides (Munro) Hack on the $30^{\text {th }} \mathrm{d}$, the Pn of it showed a slightly increase trend under the treatment of low mercury concentration (A and B) on the $45^{\text {th }} \mathrm{d}$. Nevertheless each treatment of it showed a trend of decreasing with the increase of mercury stress intensity on the $60^{\text {th }} \mathrm{d}$. This may be related to the adaptability of different turf grass species under mercury stress. But from an overall point of view, the Pn of the two species are showing a trend of decreased with the increasing of mercury stress. This indicates that the photosynthesis of the plants were affected by the mercury stress, which was similar to the results of the study of Liu-kan [8].

Stomata are the main channels of gas exchange between plant leaves and the atmosphere. $\mathrm{H}_{2} \mathrm{O}, \mathrm{CO}_{2}$ and $\mathrm{O}_{2}$ are the main diffusion gas through the stomata, so that the opening and closing of the stomata have a direct effect on the photosynthesis, respiration and transpiration of plants, and stomatal conductance is used to indicate the degree of stomatal opening. The intercellular $\mathrm{CO}_{2}$ concentration represents the concentration of $\mathrm{CO}_{2}$ in mesophyll cells between plants, which can indicate the $\mathrm{CO}_{2}$ utilization of internal environment of plant leaves. In the analysis of photosynthesis, the two indicators are combined to analyze the causes of the changes of Pn. In general, there are two reasons for the decrease of Pn of plants, one is the stomatal limiting factor, and another is the non-stomatal limitation factor. Stomatal limitation factors mainly refers to the water loss and water potential decreased caused by the stress, so as to cause the decline in Gs and the increase of stomatal resistance, then $\mathrm{CO}_{2}$ outside get into the leaf is blocked, so that the Pn decreased. The non-stomatal limitation factor refers to the electron transport chain disruption, light and phosphoric acid dissolve coupling, activity of photosynthetic enzyme such as PEP and RUBPisco decreased and photosynthetic organs destroyed of the leaf under stress. In order to determine the main limiting factor of photosynthesis, Farquhar \& Sharkey put forward the method for calculating the limiting value of the Stomata [9]. It is generally believed that the limiting value of the Stomata was related to the atmospheric concentration of $\mathrm{CO}_{2}$ and $\mathrm{Ci}$. In this experiment, the atmospheric concentration of $\mathrm{CO}_{2}$ was controlled at a constant value, therefore, the stomatal limitation was related to the $\mathrm{Ci}$. When the $\mathrm{Ci}$ was decreased, the limiting value of stomata increased, stomatal limitation was the main factor of the decline of photosynthesis. On the contrary, when the $\mathrm{Ci}$ was increased, the limiting value of stomata decreased, non-stomatal limitation was the main factor of the decline of photosynthesis $[10,11]$. This research results showed that with the increasing of mercury and the prolonging of time, the Pn and Gs of Eremochloa ophiuroides (Munro) Hack showed a downward trend, but at the same time 
the $\mathrm{Ci}$ showed a rising trend. This phenomenon indicated that non-stomatal limitation was the dominant factor of the photosynthesis decline of Eremochloa ophiuroides (Munro) Hack during the whole stress period. Similarly, the Pn, Gs and $\mathrm{Ci}$ of Axonopus compressus (Sw.) Beauv also showed a downward trend under low concentrations of mercury stress $(A, B$ and $C)$ in the early stage of treatment $\left(30^{\text {th }} \mathrm{d}\right.$ and $\left.45^{\text {th }} \mathrm{d}\right)$. It indicated that with the decrease of Gs, stomatal resistance increased, the entry of atmosphere $\mathrm{CO}_{2}$ into the stomata was restricted, and the main factor of the decrease of $\mathrm{Pn}$ is the stomatal limitation. However, with the mercury stress strength further increased and time prolonged, the Pn and Gs of it continued to decline, while the $\mathrm{Ci}$ was not affected by Gs, but showed a gradual increase. This phenomenon indicated that the leading factor was not due to the decrease of Gs, which leads to the decrease of the entry of atmosphere $\mathrm{CO}_{2}$, but the main factor causing the decrease of Pn was the non-stomatal limitation, which was caused by the destruction of the structure and function of the photosynthetic organs and the imbalance of the material and energy metabolism, so that bring about the accumulation of $\mathrm{CO}_{2}$ in the cell and showed a rising trend. To analysis this phenomenon, although a certain extent of leaf water loss was reduced by the decrease of Gs in the early stage of treatment, but the reduction of $\mathrm{CO}_{2}$ supply resulted in the $\mathrm{O}_{2}$ in the cell became the recipient of electron transport chain. Accordingly, a large number of reactive oxygen free radicals were produced [12]. Therefore, in the one hand, the stomatal limitation of photosynthesis had hindered the development of stress, on the other hand, the non-stomatal limitation was induced by the production of a large number of free radicals. The balance of production and clearance of free radicals in the turf grass had been broken under mercury stress, so then the free radical accumulation increased, the reaction of membrane lipid peroxidation intensified and the structure and function of biological membrane as well as the major molecules such as chlorophyll and protein were damaged. Then caused a series change of physiological and biochemical functions, proceed to the next step, the destruction of the structure and function of the photosynthetic apparatus and the imbalance of the material and energy metabolism in the cell had happened, thus caused the non-reversible decrease of photosynthetic characteristics.

It can be concluded that a certain degree of mercury stress can cause damage to the photosynthetic organs of turf grass, resulting in the continued decline of Pn. However, the damage mechanism of mercury on photosynthesis of plants is also need to be studied, such as the use of chlorophyll fluorescence to analyze the changes in the energy use and transformation under the mercury stress.

\section{References}

[1] D CHRISTOS and J C MAARTEN and H B PATRICK. Permeability and channel-mediated transport of boric acid across membrane vesicles isolated from squash roots, 124re ed. Plant Physiol, 2000, pp.1349-1361.

[2] M MOSTAFA. Inhibition of the photosynthetic electron transport in the unicellular green alga chlorella Kessleri by mercury at multiple sites. Cytobios, 387re ed., vol. 98. Plant Physiol, 1999, pp.25-27.

[3] G H KRAUSE and E WEIS. Chlorophy fluoresce and photosynthesis: The basics, 313re ed., vol. 42. Annual review of plant physiology and plant molecularbiology, 1991, pp.313-349.

[4] Guo-xiang Chen and Guo-xin Shi and Bin He. The effects of $\mathrm{Hg} 2+$ and $\mathrm{Cd} 2+$ on winter buds of Brasenia of photosynthetic membrane chemical characteristics and polypeptide compositions, 19re ed., vol. 5. Journal of Environmental Science, 1999, pp.521-525.

[5] Xu-huan Gu and Chun-wen Jin and Yong-zhang Wang and et al Effects of Heavy Metal $\mathrm{Pb}$ and $\mathrm{Cd}$ on Chlorophyll Contents and Photosynthetic Characteristics in Different Apple Seedlings, 36re ed., vol. 24. Journal of Anhui Agri. Sci., 2008, pp.10328-10331.

[6] Yan $\mathrm{Lu}$ and Xin-rong $\mathrm{Li}$ and Ming-zhu $\mathrm{He}$ and et al. Photosynthesis and Physiological Characteristics in Halogeton glomeratus with Heavy Metal Treatments, 31 re ed., vol. 2. Acta Bot. Boreal. -Occident. Sin., 2011, pp.0370-0376.

[7] Jun-feng Gao. Plant physiology experiment. Beijing: Higher Education Press, 2006.

[8] Kan Liu. Effects of Super Absorbent Polymer on Resistance of Turfgrass. Soochow University, 2013.

[9] Farquhar G D and Sharkey T D. Stomatal conductarice and photosynthesis. Ann Rev Plant Physiol, 1982, pp.317.

[10] Xing-yuan Zhou and Fu-liang Cao. Effects of Soil Salt Stress on the Photosynthesis of Zoysiagrass and Centipedegrass, vol. 03. Acta Agriculturae Universitatis Jiang xi ensis, 2005, pp. 408-412.

[11] Lu J Y and Shan L and Gao J F. Unsufficient irrigation and its physiological bases, 22re ed., vol. 6. Acta Botanica Boreali-Occidentalia Sinica, 2002, pp.1512-1517.

[12] Guo-yuan Yang and Lin-lin Wan and Xue-qing Lei and et al. Effects of lead and chromium on the growth, photosynthetic performance, and antioxidant activity of Scenedesmus obliquus, 34re ed., vol. 6. Acta Scientiae Circumstantiae, 2014, pp.1606-1614. 